Henri Atlan propõe que esqueçamos o livre-arbítrio cotidiano e pensemos em um determinismo decorrente de um conhecimento científico absoluto capaz de determinar a priori as causas necessárias a uma autoprodução total daquilo que existe na $\mathrm{N}$ atureza. Diante desta hipótese de trabal ho, a liberdade seria o deixar-se guiar apenas por sua própria lei predeterminada, fazer as escolhas sabidamente corretas como conseqüência do conhecimento total da $\mathrm{N}$ atureza e evitar os desvios da lei representados pelo aparente "livre-arbítrio". Atlan pede emprestado aqui os conceitos da deidade de Spinoza, com sua liberdade inerente ao conhecimento absoluto de todas as relações causais. Remete-nos à robustez, estabilidade e inexorabilidade dos processos de evolução do U niverso, guiados por um deus que sabe absolutamente.

A liberdade humana seria equivalente ao aprendizado lento em direção ao conhecimento total, contando sempre com os desvios impostos pelo erro inerente a qualquer aprendizado e que reduzem sua freqüência à medida que o ser humano aprende a lei regente do Universo. N este olhar, a "liberdade afetiva" de Kant é apenas uma perturbação da "liberdade epistêmica" de Spinoza e Atlan, que éa liberdade de seguir o caminho aprioristicamente determinado pelo conhecimento total.

Cabe aqui uma provocação que envolve a dinâmica dos processos auto-organizados, pressupostos por Atlan como os processos da $N$ atureza. N enhum processo de auto-organização digno de nota alcança seus objetivos de forma monótona. Faz-se necessária a presença de perturbações al eatórias, denominadas por Atlan e outros de "ruído", para que os processos auto-organizados não se estacionem em estados intermediários chamados de "sub-ótimos" ou "extremos locais". É o ruído que retira o processo auto-organizado dos estados intermediários não-ótimos, perturbando sua acomodação a estes estados e o lançando em estados a partir dos quais a evolução em direção ao ótimo global seja possível. A "erraticidade" de um pouco intenso mas necessário ruído al eatório é fundamental para que o processo autoorganizado constantemente possa libertar-se dos cômodos estados intermediários de equilíbrio na trajetória entre a desordem e a ordem, entre a fumaça e o cristal.

Sendo assim, a "liberdade afetiva" de Kant é um mal necessário ao alcance da "liberdade epistêmica" de Spinoza e Atlan. O livre-arbítrio kantiano é o ruído, pequeno diante do todo, porém necessário, que adiciona entropia aos processos auto-organizados da $\mathrm{N}$ atureza, permitindo que estes se libertem da comodidade dos estados sub-ótimos encontrados em seus caminhos em direção ao ótimo global, representado aqui pelo livre-arbítrio epistêmico de Atlan. Em outras palavras, a "liberdade epistêmica" de Atlan só será al cançada pelo conhecimento adquirido na "erraticidade" da "liberdade afetiva" de Kant. Ou ainda, finalizando, a "escada de jacob" da liberdade epistêmica de Atlan, que nos leva em direção aos céus, écomposta dos degraus da liberdade afetiva de Kant.

\section{O avatar da cidadania global}

The Avatar of the global citizenship

\section{Alberto Lopes $\mathrm{N}$ ajar 8}

U m santo concedea uma mulher por seus méritos um desejo. Ela expressa o desejo de poder prender todo aquele que subir na sua ameixeira para apanhar ameixas. 0 santo satisfaz esse estranho desejo. Dez anos depois, a M orte passa pe la sua casa com intenção de levá-la. Ela se declara disposta a acompanhá-la, mas antes de sair, solicita permissão para comer al gumas ameixas. A M orte trepa na árvore para buscá-las e então a mulher diz: "Que a M orte não consiga mais descer da árvore sem a minha permissão". A M orte se exalta, pede, ameaça, grita: não consegue mais descer. E ninguém mais pode morrer sobre a Terra. Todos os enfermos, os feridos, os doentes sofrem terrivelmente, pois não podem morrer. As pessoas vêem de todos os lugares pedir à mulher que solte a M orte. Finalmente, ela concorda com a condição de poder chamar a $M$ orte três vezes antes dela vir buscá-la. (Citado em Kast, Verena. Sísifo: a mesmo pedra, um novo caminho. Editora Cultrix, São Paulo, 1997, p. 72).

Sem ter condições de debater integralmente as teses apresentadas pelas autoras ao longo do excelente texto, pois isso me obrigaria a ter estudado, refletido e elaborado num grau semeIhante de profundidade as teses de H enri Atlan, permito-me apenas tecer poucas considerações
8 Departamento de Ciências Sociais da EN SP, Fiocruz. najar@ensp.fiocruz.br 
no sentido único de explicitar alguns aspectos que me tocaram em particular, colaborando assim, à minha maneira, para o debate.

Com certeza o projeto de uma consciência integral, conquistada pouco a pouco, que leve em conta as potencialidades, bem como as limitações do projeto científico humano, ganha uma resposta significativa com as elaborações atlanianas, tal qual apresentado pelas autoras. Pode-se mesmo concordar, conforme assinalado, que há uma mudança de patamar. Sem dúvida, a interpretação de Atlan dos escritos spinozianos e sua própria contribuição recente representam o que há de mais sofisticado para possi bilitar uma saída da razão, dos becos em que a própria razão nos meteu. No entanto, há uma variável que, apesar de não ser objeto de consideração das autoras, portanto podendo-se alegar que seria estranha ao debate proposto, está ausente e sobre a qual, do meu ponto de vista, é interessante refletir pois, de alguma forma, pertence, ao que parece, à ordem da execução e/ou da realização do universo atlaniano.

A variável é a política. Tento me explicar. Como a maneira pela qual a nova ética insinuada no artigo poderia, ou deveria, se traduzir num projeto educacional fundado na busca da felicidade, ocorreu-me, ao ler, uma assimetria. Qual seja? A de que essa questão introduz problemas da ordem do político e da política pública. Por que? Porque o mote do texto é 0 de contribuir para as reflexões acerca da noção de humanização (em saúde), tomada como consigna que reúne, de forma implícita, qualidade da atenção, interação compreensiva entre profissionais de saúde-pacientes e revalorização do olhar clínico, no mundo proeminente das tecnociências e das biotecnologias.

Como um conjunto de políticas pode induzir a práticas virtuosas? Como um sistema político que, em última instância representa uma coalizão de forças societais, pode ser patrocinador de políticas públicas que, por fim, questionarão, ou podem questionar, o próprio status quo que os sustenta? Como um conjunto de políticas públicas pode iniciar ou ensejar, de forma sustentada e no longo prazo, projetos educacionais que propiciarão a transformação e a superação das questões tão bem apresentadas e ponderadas pelas autoras e com especial atenção ao fato de estarmos, ao que tudo e todos indicam, num momento bastante especial da humanidade?

Do meu ponto de vista, aqui resideum ponto crucial para reflexão. As questões assinaladas no artigo pressupõem, sobretudo, uma mudança em nível do indivíduo que, essa sim, poderá produzir uma mudança societal. Ou seja, o corte epistemológico que se insinua no artigo supõe a ocorrência de uma espécie de nova revolução copernicana nas ciências sociais e humanas que, conectam indivíduo e sociedade de tal forma que enseje uma nova organização das sociedades em particular e da sociedade gl obal: uma nova forma de organização do próprio trabalho e da distribuição da riqueza, não apenas em sua acepção monetária, mas muito mais do que isso.

Nesse horizonte, estariam em jogo e colocadas em marcha questões relativas à construção do consenso e da legitimação de uma "nova humanidade", cuja realização encontra-se, ou encontrar-se-ia, numa difícil encruzilhada pois, quando se pensa nas formas e ações políticas e mesmo nas bases dessa espécie de novo contrato, apresenta-se, a meu ver, obstáculos e dificuldades de uma ordem, arrisco afirmar, muitíssimo complexa cuja perspectiva de objetivação não me parece muito simples. Como se pode pensar as bases desse novo contrato? Como imaginar um projeto educacional que teria um compromisso radical e definitivo com a liberdade responsável do ser humano e que só aceitaria como limite a sua própria capacidade (infinita) de se auto-gerir?

Sem qualquer sombra de dúvida, de meu ponto de vista, 0 artigo nos convida enos instiga a pensar e a realizar um projeto grandioso. Um projeto cujo compromisso radical com a Vida Boa, com a felicidade, com a auto-gestão, com 0 engrandecimento ininterrupto, está presente todo o tempo e cuja radicalidade deve ser renovada a cada momento eque de al guma forma apresenta o Paraíso, não como um Jardim das Delícias de onde se foi expulso, mas como um jardim cultivado na medida certa da responsabilidade compartilhada, a partir de uma mudança no plano individual, base sólida para a mudança societal. 